\title{
An Investigation Into the Livelihoods Strategies of Informal Women Traders in Zimbabwe
}

\section{Stella Takaza ( $\nabla$ stellatakaza@gmail.com )}

University of Zimbabwe

\section{Chipo Chitereka}

University of Zimbabwe

\section{Research}

Keywords: Flea Markets, Micro Credit Schemes, Poverty Eradication, Informal Women Traders

Posted Date: December 18th, 2020

DOl: https://doi.org/10.21203/rs.3.rs-22701/v2

License: (c) (i) This work is licensed under a Creative Commons Attribution 4.0 International License. Read Full License

Version of Record: A version of this preprint was published at Journal of Innovation and Entrepreneurship on March 31st, 2022. See the published version at https://doi.org/10.1186/s13731-021-00175-3. 


\section{Abstract}

This article investigated the livelihoods strategies used by various informal women traders doing business in the Hare Business Districts of the Harare Province. The study was informed by the Sustainable Livelihood Approach proffered by the Swedish International Development Cooperation Agency Division (SIDA, 2001) for Policy and Socio-Economic Analysis. A quantitative and qualitative research design was utilized and data was gathered through questionnaires, in-depth interviews, focus group discussions and direct observations during transect walks. The objectives of the study was to; identify micro-credit schemes used by the informal women traders doing business at flea markets, explore the livelihoods of microcredit schemes as pathways towards poverty eradication and finally determine possible interventions and sustainable strategies that could be used for the informal women traders. The study revealed that women informal traders engaged in diverse activities for sustainable livelihoods strategies that eradicate poverty. Numerous informal women traders face staid livelihoods challenges, resulting in them living in dire poverty. The study calls on Government and financing institutions to finance them for local empowerment as well as gain access and control of available livelihoods resources in a meaningful way. Thus comprehensive policy interventions and sustainable strategies would enable informal women traders doing business at flea markets to eradicate poverty in Zimbabwe.

\section{Introduction}

The problem of limited livelihoods resources is a staid threat among scores of women worldwide, predominantly in developing countries including Zimbabwe. The majority of the women in developing countries are engaged in the informal sector, moreover a higher percentage of people working in the informal sector, relative to the formal sector are poor (United Nations, 2000, Brown, 2006, Chirisa, 2013). This study was conducted to investigate the livelihoods strategies used by the women traders in the informal sector doing business at flea markets. The descriptive and exploratory study was conducted within the Harare Central Business District (CBD) of Mashonaland East Province. The target population was drawn from 90 informal women traders and 10 informal men traders to represent. The study was informed by the Sustainable Livelihood Approach proffered by the Swedish International Development Cooperation Agency Division (SIDA, 2001) for Policy and Socio-Economic Analysis. Data analysis applied qualitative and quantitative methods. Statistical Computer Software Package (SPSS) was employed and later triangulated to comprehend the significance. This paper is organized in themes that include; background to the study, literature review, and research methodology, discussions, policy implications and way forward. Finally, the conclusion is drawn from the discourse analysis.

\section{Background To The Study}

The informal sector plays a critical role in addressing the problem of insufficient livelihoods, particularly in developing countries including Zimbabwe. More recently, world literature (Pe' rez-Escamilla, 2017; World Report, 2020) confirm that; "close to 800 million individuals had no access to sufficient food, 2 
billion individuals experienced key micronutrient deficiencies, and 60 per cent of individuals in lowincome countries are livelihoods insecure". These challenges have been experienced mainly among the informal women traders doing business at flea markets. The proportion of women in the informal sector exceeds that of men in most countries (Chirisa, 2013). This study is therefore calling for obligatory response to address the multifaceted systemic issues in the form of an investigation to make it lucid for the informal women traders. The research inquiry of this study includes the following;
a. Where are these informal women traders operating from daily or yearly?
b. What are the livelihoods strategies used by the informal women traders?
c. What challenges do they face when they do their businesses at flea markets?
d. What survival and coping strategies do they use?
e. What is being done for them to address the problem?

The concern of this study emerges because earlier studies reveal that these questions have not been addressed in adequate detail. There is a broad lane of unpublished works on the livelihood strategies used by the informal women traders doing business at flea markets. This groundbreaking research acknowledges the substantial gap which substantiate that these vulnerable groups face difficulties in accessing livelihoods resources to sustain under diverse and complex socio-economic conditions. The state of affairs in decades has been reported to be worse in the inner circles of the densely populated metropolitan cities such as the HCBD of the Mashonaland East Province of Zimbabwe. Thus, informal women traders proliferate in the face of multiple livelihoods challenges for as long as there are no appropriate interventions to counter the side effects of the limited livelihoods and their impact attendant of socio-economic hardships. Mupambireyi (2014) enlighten that, be it in the developed or developing countries, economic activities can be categorized into two; formal and informal sector. "Poverty is the inability to attain a level of well-being constituting a realistic minimum" (The Zimbabwe Poverty Report (ZPR, 2017). Even though some are expected to benefit from livelihoods activities, the HCBD prove the multi-faceted socio-economic problems that have continued to subject many informal women traders to chronic and acute poverty. It has been broadly realized that women have many needs although limited livelihoods resources available for them to sustain during diverse and complex economic circumstances.

Against this backdrop, this study is left with no option other than breaking the ground and carries out this research on the livelihoods strategies used by the informal women traders. Chirisa, (2013) confirms that "women tend to work in the invisible sectors of the economy". The study seeks to close the wide gap of livelihoods invisibility of the women traders that has remained unchallenged and have been getting worse over the years. The particular study is undertaken to investigate varieties of livelihoods strategies used by women traders in the informal sector. The research focuses specifically on the existing savings and Micro-Credit Schemes, (MCSs) of the informal women traders doing business at the flea markets. The explorative study is conducted with the view to unpack uncompromising scarcity of livelihoods resources among informal women traders doing business at flea markets within the HCBD. These livelihoods 
scarcity issues seem to undergird and perpetuate the problem of poverty among these vulnerable groups. Moreover, this is happening against the background wherein the World Bank, (2015) observed that the country was once a breadbasket for the Southern Africa region and beyond. Hence, the prime concern of this study is to observe how informal women traders do their business for poverty eradication under the prevailing socio-economic hardships. The motivation for this quest is to capture the number of flea markets and informal women traders engaged in savings and micro credit schemes for poverty eradication. The study is expected to proffer innovative practical interventions and sustainable strategies which both the Government and Financial Institutions, as well as the informal women traders, can apply, respectively, when dealing with abject poverty in Zimbabwe. The study is fundamentally informed by the Sustainable Livelihoods Framework proffered by Swedish International Development Cooperation Agency (SIDA, 2001); a Division for Policy and Socio-Economic Analysis; an action programme that specifically promotes sustainable livelihoods for the poor. Chirisa, (2013) confirms that; "there is an overlap between working in the informal sector and being poor".

\section{Literature Review}

The world literature shows that livelihoods insufficiency among vulnerable women masquerades serious threats with great potential to cause global civil unrest and poverty to many people, especially that of informal women traders in developing countries. Pieces of literature confirm that in the past, the livelihoods shortages among women traders doing business at flea markets have not been studied and understood in adequate detail. This review therefore presents literature that systematically speaks about the problem of livelihoods among informal women traders from local, regional and international perspectives. Adeel, (2017) emphasize that "a comprehensive approach requires the broad engagement of stakeholders; states, civil society organizations, FBOs, social workers, private businesses and industries, researchers as well as social scientists at all levels. The United Nations Systems (UNSs); regional commissions, international, regional financial institutions and other donor agencies have been well-known to be concerned with endless efforts that engage in joint partnerships to eradicate poverty in the developed countries. These reviews demonstrate that global efforts look as if they endlessly fall short to address the needs of informal women traders in developing countries such as Zimbabwe. The women have countless fundamental needs but limited livelihoods resources available for them. This review in that regard is concerned with the livelihoods of informal women traders doing business at flea markets. Several kinds of research have been conducted devoid of investigating how informal women traders attain sustainable their livelihoods at the grassroots level. The United Nations Decade for the Eradication of Poverty (1997-2006); the United Nations Millennium Development Goals (UNMDG, 2015) and the Sustainable Development Goals, (2015) initiatives highlight the need to eradicate poverty using various strategies. Despite multiple efforts of these United Nations agencies, it has been established that there are substantial gaps in the scientific literature that have remained unchallenged with regards to livelihoods interventions targeting women traders.

Besides, some stakeholders equally strategized to implementa the 2030 Sustainable Development Goals (SDGs); especially Goal No 1 with a thrust to end extreme poverty in its form. A piece of literature justifies 
that progress on sustainable livelihoods of women traders doing business at flea markets lags. The way forward, some stakeholders agreed at the global level to manoeuvre the implementation of the Sustainable Development Goals (SDGs, 2015) for poverty reduction. Although works of literature confirm that some developing countries have adopted these devices, many informal women traders have been perceived to experience poverty and the copious escalating cost of basic commodities and reduced livelihoods resources. The World Summit for Social Development (WSSD) held in Copenhagen in March 1995 emphasizes the significance of improving access to savings and credit schemes for people with low or no income; with special consideration on the needs of the informal women traders. Srinivas (2005) and Karlan (2005) pronounce that women approximately constitute 75 per cent of savings and micro credit schemes recipients worldwide. The United Nations (2012) re-affirms that IWTs engage in these schemes which could unleash the potential of hundreds of millions of the worlds' poorest which was not the case before. The global observations necessitate the quest for this review to investigate the livelihoods strategies which have impacted on informal women traders who energetically endeavour to fight poverty in successive periods of economic hardships at the global level.

In Sub-Saharan Africa, poverty eradication by informal women traders doing business at flea markets has become a common phenomenon and become a major concern. The main thrust at the regional level is to gain an appreciation on the livelihoods difficulties faced by the informal women traders. The quest is to comprehend how the majority of women access available livelihoods under the prevailing socioeconomic hardships. Mupambireyi (2014) is of the view that developing countries have been plagued with a plethora of challenges which had scuttled economic growth. Richman (2009) added that regionally, savings and MCSs by several informal women traders at flea markets have been successfully done in countries like India, Ethiopia and Kenya. Despite these lucid observations, the problems of poverty among informal women traders seem to persist in some countries in the region akin to Zimbabwe. The Microfinance Bulletin (2006) for example substantiate that Asia comprises 70 per cent of the world's microfinance account holders, Latin America made up another 20 per cent, and the remaining 10 per cent are scattered throughout the rest of the world. The African continent comprised merely 4 per cent of the overall population which had access to savings and micro credit schemes. The mainstreams of IWTs doing business at flea markets seem to predominantly access livelihoods through savings and MCSs to improve the standard living of the poor. Comparable studies confirm that if provided with the necessary tools, savings and MCSs benefit IWTs by allowing them to have successful businesses at flea markets that unleash acute poverty. Studies conducted by Srinivas (2005) and the Grameen Bank (2012) confirm that when implementing savings and MCSs, attendance by members is compulsory for the repayment of loan instalments and the collection of savings. Some meetings of IWTs reinforce a culture of discipline, routine repayments and staff accountability. An informative study in India, (2012) on MCSs revealed that 18 per cent of the overall population especially women had some form of microfinance accountwhich protected its members from whichever eventualities. Richman (2009) corroborate highlighting that poor women in Ethiopia, India, and Kenya have been excluded from government savings and lending schemes or faced prejudice in banking systems other than benefiting from savings and MCSs to form successful businesses to enhance their livelihoods. The savings andMCSs success examples are documented in 
countries such as Latin America, Bangladesh, India, Thailand, Indonesia, West Africa, Southern Africa and Kenya amongst others. The variances demonstrated by these practical examples have shown that savings and MCSs programmes by informal women traders demonstrate a significant gap related to small loans meant for the poor people; especially IWTs doing business at flea markets. Literature has shown that these self-employment projects generate income, allowing members to care for themselves and their families. Although the achievements of the Grameen Bank in Bangladesh have been considered the most prominent of the success stories reaching over 2 million people with cumulative lending of about USD2.1 billion, the problem of poverty among many informal traders persist. Pieces of literature show that the Grameen Bank is responsible for making available savings and MCSs to women that prove high payment rates which is partly outstanding to the practice of weekly public meetings in the informal sector. Chirisa, (2013) argues that despite these challenges, women in the informal sector have to come up with their own coping strategies that enable them to continue with their trade.

Locally, the Zimbabwean economy has been characterized by macroeconomic imbalances such as high budget deficits, the balance of payment deficits, inflation and low economic growth "(The World Report, 2017). The majority of informal women traders in the HCBD of the Harare Province for example endeavour to outsource livelihoods resources at flea markets to address the imbalances in livelihoods experienced in their families. Zimstats (2013) and the Zimbabwe Poverty Report (2017) proffer that Poverty and Poverty Datum Line Analysis (PDLA) in 2011/12 was pegged at 62.6 per cent of households who are deemed poor whilst 16.2 per cent are living in extreme poverty. The Poverty Datum Line as defined by the Zimbabwe Poverty Report (2017) reflects the cost of a given level of living standard which must be attained if a person is deemed not to be poor. In addition, Zimstats (2019) figures demonstrate that poverty in Zimbabwe is high (72.8 per cent) among households without salaried workers as compared to those with a salaried worker (38.5 per cent) living below the PDL. These figures illustrate that individual poverty in Harare Province is (3.8 per cent) (Zimstats, 2019). These figures demonstrate that the impact investigation will help to discover a fresh trajectory into the existing body of knowledge and proffer novel perspectives on best practices and policies for IWTs doing business at flea markets. Several women in the past have been obliged to employ hard-hitting strategies that directly encroach on their anticipated livelihoods resources which subsequently compromise their standard of living significantly. Previous researches have targeted women in general without specifically focusing on poor women doing business at flea markets. Chirisa, (2013) states that "informal sector players operate in a risky terrain such that women have experienced a lot of challenges that have affected their lives". That's why this review identified the blow thrown in the face of the informal women traders doing business at flea markets in the HCBD of the Mashonaland East of Zimbabwe. The innovative study will supply solutions to the problem as it affects the women in the informal sector in the near future. The study will endeavour to intervene effectively to interrogate the socio-economic and livelihoods and evaluating the policy implications on women doing business at flea markets. The results of the study will develop into best practices by suggesting comprehensive policies on livelihoods that benefit informal women traders to eradicate poverty. 


\section{Conceptual Overview}

This particular study is informed by the Sustainable Livelihood Approach (SLA) proffered by the Swedish International Development Cooperation Agency Division (SIDA, 2001). The SLA was developed for Policy and Socio-Economic Analysis Livelihoods that comprise "the capabilities, assets including both material and social resources and activities for a means of living which is sustainable when people can cope with and recover from stresses" (Ian Scoones, 2009). The SLA in the formal and informal sector goes beyond the conventional definitions and approaches to poverty eradication (Krantz, 2001). Both the formal and the informal sector contribute to shaping the lifestyles of the ordinary people during socio-economic and environmental hardships. Most Government kinds of literature enlighten that salaried workers in the formal sector denote workers in registered enterprise and unsalaried workers in the informal sector represent workers in the unregistered businesses or activities for poverty eradication. Thus IWTs normally get involved in MCSs at flea markets for poverty eradication. Chambers and Conway (1992) describe Sustainable Livelihoods as the capabilities, assets together with both material and social resources and activities used by a household for means of living. Chambers and Conway agree that a livelihood is sustainable only after which say people are bound to cope with and recover from stress and shocks, maintain or enhance its capabilities and assets, and provide sustainable livelihood opportunities for the next generation. The assets contribute to other livelihoods at the local and global levels and in the short and long term period. The SLA in that regard becomes fundamental because it captures diverse techniques that address the essential requirements of an individual, household, and community. The Institute for Development Studies (IDS) and the British Department for International Development (DFID) have been putting into operation the SLA (Kantz, 2001). This approach has been preferred for this study because it relies on various types of 'capital' and human, social, natural, physical, and financial, as well as socio-economic and political structures and processes at the household level. The IWTs usually engage in MCSs at flea markets which are designed to maintain the family units in reducing poverty by facilitating access to capital, livelihood strategies and decision-making powers through processes, such as policies, legislation, institutions, culture, and power relations. Several IWTs at flea markets take to the stage and decide to make livelihoods differences in poverty reduction as the majority tends to be exposed to whichever form of challenges when there are no appropriate institutional intervention strategies. The situation is the portfolio of assets out of which people construct their living through tangible assets and resources (Krantz, 2001). Thus, pressure in attaining livelihoods by the informal women traders at flea markets tend to increase and force them to live below the PDL; hence the need for further investigation.

\section{Research Methodology}

\section{Data Collection methods}

The descriptive and explorative study used the survey method. Thus questionnaire tool guides were used to collect quantitative and qualitative data. Most data was gathered through in-depth interviews, informal conversations, Focus Group Discussion (FGDs) and participant observations. In-depth interviews were conducted with the respondents only willing to be researched on. The sampling design was based on 
geographical location, meaning that the respondents were representative of the informal women traders doing business at flea markets in the locality.

\section{Location of the Study}

The study was conducted in the HCBD of the Mashonaland East Province. The district was selected because the constituency is prone to hosting copious people migrating from the entire corners of the country to the Metropolitan City for various reasons. These people include women and children, younger people who are always on the move to the greater Harare for greener pastures. The district was also selected because of its networking position with the main roads from other cities or rural areas facilitating the transportation of livelihoods resources and people; making it a leading economic zone. The HCBD in the past used to host only the working-class population and yet these days everyone aspires to be identified with quality city life.

\section{Study Population}

The unit of analysis for the study applied stratified and purposive sampling in which 90 informal women traders aged between 22 and 50 years were sampled to participate in the study. As well as 10 key informants comprising men doing business at the flea markets were selected to participate in the study. The sample comprised 100 people in totals.

\section{Data Analysis}

Data was collected guided by the Livelihoods Strategies developed by SIDA, (2001). Quantitative data Analysis utilized the Statistical Package for the Social Sciences (SPSS) Computer Package for descriptive presentation. Thus qualitative data analysis was completed using topic ideas and themes that emerged from in-depth interviews. Also, quotes were taken from respondents' transcripts through indepth interviews to demonstrate thematic materials. Summaries of the findings, discussions, policy implications, conclusions were drawn from the discourse analysis.

\section{Ethics In Research}

All through data collection, research ethics and privacy were observed to respect the privacy of the respondents. The researchers sought maximum consent from the respondents themselves and made it comprehensible to them that the collected information was purely for academic purposes. All the same, the researchers were responsive of the sensitive nature of the study and the implications of observing informed consent. Neuman (1997) define ethical considerations as what is or not legitimate to do or what is 'moral' when conducting scientific research. The names and places used are not their real names and places. As such, pseudo-names were used throughout data presentation. The respondents agreed to contribute to the study and the collected information was kept in confidence to protect the respondents.

\section{Results And Discussion Of Findings}


The study investigated the livelihoods strategies of the informal women traders involved in savings and micro credit schemes in the HCBD. A good rapport conducive for a mixed-method was established with the respondents to determine intervention strategies that develop the livelihoods of the informal women traders. Data were gathered in the following parameters; Socio-demographic profile of the respondents, the nature of the business, the formation of MCSs, types of lending schemes, profit sharing and terms of payment, member's benefits, challenges encountered, why women engage in micro-credit schemes, policy implications, the way forward and conclusion.

\section{Socio-Demographic Profiles of the Respondents}

The first data presentation involves the profiles of informal women traders and informal men traders to represent.

Figure 12 shows the demographic profiles of the respondents who participated in the study. These were 90 informal women traders doing business at flea markets and 10 informal men traders doing business at the flea markets to represent. Chirisa, (2013) observed that "in general terms, women have more challenges than men". The ages of the respondents ranged from 22 to 50 years.

\section{NATURE OF BUSINESS}

The third data presentation involves the nature of the business of the informal women traders. The studyexplores the sources of livelihoods of informal women traders doing business at the flea market.

\begin{tabular}{|ll|}
\hline Traditional Handicrafts & Imported Items \\
\hline Handmade bags & Clothes and hand bags \\
\hline Crocheted garments & Children's toys \\
\hline Basketry & Blankets \\
\hline Handmade mixed products & Kitchen wares \\
\hline Weaved/ knitted garments & Shoes \\
\hline Traditional pottery & Accessories \\
\hline Locally made weaved floor mats & Furniture \\
\hline
\end{tabular}

Source: Analysis from in-depth interviews

Table 1 shows the nature of businesses of the IWTs at the flea markets. The 90 informal women traders and 10 key informants indicated that they were involved in savings and MCSs at the flea market. The majority of the activities were on buying and selling assorted local and imported goods that ranged from traditional handicrafts, clothes, handbags, blankets and kitchen wares to children's toys. The IWTs were 
also selling handmade mixed products comprised of weaving, knitting, and crocheting whilst others were selling imported products from other countries. Several reported that they were selling traditional products such as pottery, basketry, locally made weaved floor mats.

The respondents indicated that they engaged in various savings and micro-credit schemes because some individuals found themselves living in poverty. Mulwa, (2008) says "micro savings and credit schemes refer to more structures saving and loaning facility created and managed by its members". These loans are loans acquired informally from people in the same network, and formal credit lending institutions like banks and microfinance institutions (Mugabi, 2010). The motivation of the study was to appreciate the challenges and copings to suggest comprehensive interventions and sustainable livelihoods strategies that could be used by the informal women traders. The vast majority of informal women traders were involved in savings and MCSs at some flea markets in the HCBD which became attracting centres for women who aspired to do business and MCSs. These activities were planned to outsource the required livelihoods, enhance socio-economic development, setting standards for poverty eradication and improving the living standards. The majority of IWTs had a long tradition of working together as groups based on social relationships revolving around kinship ties, gender or village memberships. The study found that for IWTs selling local products, their business was lower than those selling imported goods since some considered the local products to be of cheap quality than the imported products. Several IWTs indicated that some consumers prefer expensive materials regardless of higher prices. The researchers' observation was that the emergence of imported products from other countries had pushed aside the local products. This influenced the position of informal women traders in boosting income in a meaningful way under the prevailing economic hardships. The informal traders who imported products for sell tended to benefit more than those who sold local products.

\section{Quality of Micro Scheme Investment}

The fourth data presentation is from the findings on the quality of savings and microcredit investment used by the informal women traders doing business at the flea markets. The response shows that IWTs at flea markets were involved in MCSs not governed by any legislation or policy frameworks. Mupambireyi, (2014) confirm that "the informal sector operate outside the realm of official regulatory frameworks and workers are not registered, regulated or protected under the labour legislation and social protection". The IWTs mobilized themselves and planned their MCSs of their interest with affordable rules and regulations they understand better. Through pooling the resources together based on the group or socio-economic ties to form savings and MCSs (locally known as rounds or mukando), some women grouped themselves together in a participatory and comprehensive approach. The groups contributed a certain agreed amount of money per week or month. The women traders decided among themselves on how they used the money though bound by a simple constitution which stipulates written down rules and regulations. The group rules guided the operations of their schemes on certain aspects for example registration, contributions, benefits and code of conduct. Zheke (2010) confirms that when the group is too big, the group members can be subdivided into smaller units of ( 6 to 20 ) members to manage their schemes efficiently and effectively. The grouping process is usually reported to be simple as it does not need any 
paperwork. Zheke added that some groups are usually small and structured after preliminary meetings are held to decide how many should be in a group and how much each member was to contribute per day, per week, per month or year. Zheke affirmed that normally interested groups are invited to join the rounds or mukando based neither on their educational background nor economic status. In reality, these are based on characteristics such as trust, honesty, reliability, and punctuality, savings potential and locality and many more. Once the group is structured, members decide on when to meet and how they want to share the generated profits basing on the group constitution. By pooling financial resources together, women manage to improve the sources of livelihoods which ultimately increase resilience to risks and shocks such as illness, death in the family as well as pay medical bills. If a member changed a place of residence from the particular flea market to another, the respondents indicated that this automatically disqualifies an individual from being a member of savings and MCSs. The departing member will join another group where she is going to operate from. One IWT member reported that she had not joined any group but had decided to do a self-motivated scheme for the reasons best known to her. The woman informed that she had constructed a self contribution strategy in which at the end used the money to purchase items from foreign countries which she sold at the flea market. The self-motivated respondent had this to say;

"I decided not to join the group but rather to do it alone and every day I put aside a certain amount. On the first day, I put aside one dollar, the second two dollars, the third three dollars and so forth until the end of the month in which I raised USD460 dollars for myself. I used the money to order new items or for any other contingencies and me this works very well" (Interview with the informal woman trader 20 June 2018).

The savings and MCSs' arrangements fostered motivation among women who seized the stage and decided to make a distinction in their lives. Mugabu (2012) aver that "the provision of MCSs in such a measure is meant to reduce the burden of poverty among households wherein interveners can support schemes in the form of loan procedures and paperwork, combined with accounting experiences especially access to formal sources of credit". The savings and MCSs at flea markets operate devoid of policies and legal frameworks to protect their investment that require some form of interventions by Government and financial institutions to protect and empower the vulnerable Informal women traders doing business at flea markets.

\section{Terms of Payment and Profit Sharing}

The fifth data presentation narrates the terms of payment and profit-sharing among the beneficiaries.

Figure five illustrates how some respondents paid back the loan. Some though expressed that they were failing to pay back the loan on time. "A typical and predominant problem in saving and micro-credit scheme is loan defaulting" (Mulwa, 2008). Those who reported failing to pay back the loan on time were fined as per the agreed amount. Some women paid the agreed amount every week whilst others paid back every month without being charged interest and others were charged interest. Even though some members were comfortable with the terms of payment, others expressed that they were not satisfied and 
uttered dissatisfaction with the terms of payment. A few members complained with regards to the method of payment, time of payment and the interest payable to the lender. Mulwa, (2008) enlighten that the principle operating with savings and credit scheme is saving regularly, borrowing wisely and repaying loans promptly as agreed with the group. However, some women borrowed the agreed amount and paid back the loan with or without interest charged on them.

Several IWTs provided financial support as short term loans (merry-go-round) to their members under a special arrangement. Merry-go-round is also a localized initiative of informal savings and credit facility which is usually organized among very close friends (Mulwa, 2008). The money contributed by members is usually not kept in whichever bank account other than alternatively circulating within group members where terms of payments are stipulated. The women doing business then share profits after every six months and sometimes give each other groceries for example salt, sugar, salt, cooking oil and soap. Some members indicated that they received less than $\$ 200$ per term whilst the majority articulated that they received above $\$ 500$ more than others which revealed some variances in their administration. Mulwa, (2008) clarify that group members in both merry go round and savings and credit schemes contribute equal amounts of money on a regular basis. However, a handful of poor women highlighted that they struggled to pay back the loan. The informal women traders found themselves paying back the mortgage through other sources apart from the benefits through tokens or gifts from relatives which even made it difficult to translate into loan interest. These terms of payment and profit-sharing among informal women were a good strategy, although there is a need to put in place clear guidelines to avoid possible conflict and misunderstandings among the group members. Mulwa, (2008) aver that "savings and credit schemes are not meant to give charity, neither is it meant to maximize on profits, but simply to give service to its members at cost".

\section{How Women used the Money Borrowed}

The sixth data presentation narrates how informal women traders used the money they borrowedfrom the savings and MCSs.

Figure 6 illustratehow women used the money borrowed from the scheme. The responses explain that the borrowed money was used for the following; buying and selling was reported (14) food kinds of stuff (24) and bus fare expenses (26), property investments (13), education (11) and health care (12). The highest expenditure was on food staffs whereas the lowest was medical bills. Although the amount agreed upon was small, some members found it difficult to pay back the loan on time. For example, one member expressed that she was raising money to pay hospital bills for a relative diagnosed cancer in the amount of (USD1, 800) and the money was insufficient to meet those costs. Mulwa, (2008) enlighten that the amount is usually too small for formal requirements of most commercial and financial institutions. The scheme generated reasonable income that improved the living standards of the very poor, and set reasonable standards for poverty eradication.

A few group members revealed that they managed to send their children to school, accessed quality health care, improved their living standards, paid monthly rentals on time, and bought new stands. Most 
remarkably, one member revealed that she was able to purchase a motor vehicle. Berhane of Action Aid (2009) concurs indicating that more resources in the hands of women mean better health, quality living standards and education for the whole family, as women spend the money on schools and medicines for their children. The majority of informal women traders reported that they needed money to purchase various items for various reasons. Thus lessons learned from the Grameen Bank, (2012) confirm that MCSs allowed women to care for themselves and their families. The findings demonstrate that IWTs use the money borrowed from group schemes to address their special needs which they were not able to do before. Mulwa, (2008) conclusively corroborate citing that "savings and credit schemes are built on the assumption that everybody will have something to save no matter how poor".

\section{Reasons why Women Engaged in Micro Credit Schemes}

The seventh data presentation shows thereasons why women engaged in savings and MCSs at flea markets.

Figure 7 shows the reasons why IWTs preferred to engage in savings and MCSs while doing business at flea markets. The responses varied as some expressed that they joined the schemes to share risks (10), to plan for the future (15), for economic reasons (20), pulling resources together (25) and sharing experiences (30). However, the responses on sharing experiences were the highest whilst sharing risks was the lowest. The IWTs carry out business at flea markets mainly to sell their products and share experiences. Chirisa, (200013) aver that life in the informal sector is not as easy as it seems in which informal sector players operate in a risky terrain which require the competitors to come up with their own coping strategies that allow them to continue with their trade.

The other reasons why women joined savings and MCSs were to provide them with a base from which they can protect themselves against any form of contingencies. Some added that risk-sharing and pooling resources together for poverty eradication were the foremost reasons. The responses explain that informal women traders decide to provide capital to the marginalized women who are unable to access loans. Zimbabwe Poverty Report (2017) buttress that in urban areas, poverty is the highest among households that depend mostly on their business. The schemes facilitate the IWTs to gain access and control of livelihoods resources and to eradicate poverty where opportunities prove limited otherwise.

Some IWTs are proficient to invest in such businesses and secure distribution channels to start making more money consistently. Purohit, (2012) corroborate stating that informal women traders engage in savings and MCSs for empowerment and as resolute pathways to eradicating poverty. Some indicated that in the past, informal women traders failed to qualify for traditional loans provided by Commercial Banks. This is why scores of IWTs decided to join the savings and MCSs as sources of livelihoods to cushion them and for poverty eradication. The poor women in general have no collateral security and funds to pay back the loans. Mulwa, (2008) aver that contributions mark up should be affordable to all members of the group, including the economically poor. The micro-enterprise owners can then begin enduring and thickening their pockets and thus narrowing the Poverty Datum Line (PDL). SIDA (2001) corroborate averring that "there is a need to access capital, livelihood strategies, and decision-making 
power through processes, such as policies, the legislation". Some positively indicated that the involvement in savings and MCSs in a critically strained economy is fundamental because the initiatives escort them to overall economic growth. Individuals are bound to acquire a steadier income which makes it possible to buy more products to sell and generate extra income for them to sustain. Kofi Annan (2012) aver that savings and MCSs are a wise investment in which women who are regarded as a minority group are likely to venture into initiatives even if they encounter social and economic challenges more than their female or male counterparts who are not part of the scheme. In the past, it is acknowledged that IWTs did not have protected ways and means to save the money but with the MCSs fortunately, IWTs prove proficient to earn hard cash which is bound to circulate among its members for them to purchase items and sell them later.

\section{Challenges Faced by Women in Poverty Eradication}

The next data presentations illustrate the challenges faced by IWTs doing business at flea markets to explore on sufficient sustainable livelihoods for poverty eradication.

\section{Table 2: Challenges Faced by informal women traders}

\begin{tabular}{|lll|}
\hline Type of Challenge & Frequency & Expected outcome \\
\hline Lack of Start-up capital & 30 & Poverty \\
\hline Unpredicted weather patterns & 15 & Reduced income \\
\hline Harsh economic conditions & 30 & Low income and poverty \\
\hline Lack of policy and legal frameworks & 10 & Poor management \\
\hline Limited net working opportunities & 12 & Economic lsolation \\
\hline Increased completion among IWTs & 17 & Conflict and misunderstanding \\
\hline Depressed consumer demand & 33 & Reduced product interests \\
\hline Lack of proper working infrastructure & 15 & Burglary and products damage \\
\hline Lack of proper management ethics & 20 & Violation of customer rights \\
\hline Lack of markets to sell their produce & 20 & Reduced income and poverty \\
\hline Lack of incentive ad subsidies & 06 & Apathy or reduced morale \\
\hline
\end{tabular}

Source: Analysis from in-depth interviews

Figure 5 confirm some of the challenges faced by IWTs at flea markets whilst attempting to eradicate poverty. Women who faced challenges with regards to lack of start-up capital, constituted 30 and unpredicted weather patterns recorded 30. Harsh economic conditions and lack of legal policies to 
protect their businesses was 15 . The slightest was those respondents who lacked networking opportunities which recorded 10. Additional challenges include; increased competition, depressed consumer demand and lack of proper working infrastructure. Several respondents communicated that they faced challenges in paying back the loan. When they borrowed money from the group, some did not fully understand the permissible terms associated with the loans. Mulwa, (2008) is of the view that "women decide on the savings or contributions within their financial capacity". The majority indicated that sometimes individuals receive loans with good terms but fail to understand the requirements because some take the loan devoid of complete information on how individuals repay the loan.

The respondents highlighted that unpredicted weather conditions as some of the challenges encountered by women doing business at the flea market. Women communicated that some of the items sold at the flea market were seasonal. Those selling winter and summer clothes faced challenges due to change of weather from winter to summer and vice versa which always leave them with abundant stock after every season. This affected their business and ability to pay back the loan. The majority expressed with concern that there were no proper structures to secure their items during the rainy season. Several women reported that sometimes they were forced to close their stalls as individuals had no proper roof or building structures to store their products during either hot or rainy season; hence for them their business was a loss.

The other challenges describe personal problems such as paying school fees, hospital bills and rent which was a good excuse for not being able to pay back the loan within a stipulated period which necessitated dropping out of members. Mulwa, (2008) propound that "inconsistency in contributions and rate of drop-out among the members sometimes leads to low morale among the group members". Thus sickness and death in the family have been cited as another major cause for not opening the business for some time. A few members disclosed that when they are bereaved, the affected members close their businesses for days, weeks or even months to recover from grief and bereavement after losing their dear ones. The respondents disclosed that, traditionally, the bereaved cannot sell or even join the scheme to gain profit in a meaningful way.

Lack of proper management expertise and misuse of funds was some of the challenges experienced by members who expressed that this affected their business. A few women were said to be misusing the money purchasing luxury items instead of generating profits for the business as well as paying back the loan on time. During interviews, one woman always mentioned that the money was used for "personal items"which some of the group members regarded as misuse of funds. Mulwa, (2008) warn that dishonesty has often led into premature withdrawals of those who have benefited, thus creating conflict and protest from those who are still waiting for their turn". When the researchers probed further for clarification on the issue, the responded was undecided to simplify what she meant by the word "personal use". The researchers concluded that there was a lack of proper mechanisms to check-up on the proper use of funds among women micro-credit operators. It was clear that the women encounter adversaries at the flea market. Mupambireyi (2014) reveals that those deposited involuntarily in the informal sector due to the Economic Structural Adjustment (ESAP) in the early 90 s are facing a raft of challenges. 
Another comparable challenge was that there was a missing subsidies, incentives and policy guidelines on savings and MCSs for women doing business at flea markets for poverty eradication as there were few de-motivating factors. Several respondents also highlighted that when they strive to import goods for sale, occasionally these are confiscated at the border post or they faced hassles at the border post. Several respondents expressed that sometimes officials besiege their goods demanding immigration declaration forms for some imported wares.IWTs mentioned that in as much as they wanted to work according to the law and regulations but at times they are uninformed and as a result are forced to hide some of the goods and not declare them. Chirisa, (2008) reveals that the transactions are usually not documented and those who participate in such trade do not pay taxes to the revenue authority. The respondents constantly expressed that officials at border posts sometimes clash with vendors who sometimes fail to prove that their wares have been officially declared at the country's designated entry points. Some respondents mentioned that when they declare goods at the border post, some due to illiteracy find nowhere written that one should keep safe the declaration forms for future reference. Murwira (2012) observed that some vendors imported goods in bulk and sell them at different flea markets across the HCBD which makes it difficult to keep the required declaration forms at the selling points. As a result, the border post officials encounter some deceptive vendors who miss out some declaration processes at each country's entry points which deprive the state millions of dollars in revenue. Murwira (2012) in that regard emphasize that that those officials track them down and collect what is due to the state.

\section{Policy Implication And The Way Forward}

Thus comprehensive policies and programmes targeting women doing business at flea markets are appropriate strategies for poverty eradication in Zimbabwe. The Sustainable Livelihoods Strategy propounded by SIDA, (2001) places emphasis on the realization that poverty - as conceived by the poor themselves; is not just a question of low income, but also includes other dimensions such as poor health, illiteracy, lack of social services, etc., as well as state intervention. Accordingly, women in the informal sector encounter multi-dimensional challenges related to poverty which appear to be overlooked by policymakers. The common informal sector activities are carried out by the road side, in homes, flea markets, and as they walk (Suwal and Pant as cited in Chirisa, (2013). The informal sector therefore require immediate intervention strategies through comprehensive policies and programmes that target informal women traders involved in savings and MCSs at some of the designated points to eradicate poverty. The Zimbabwe Poverty Report (2017) confirms that; "eradicating poverty is a top priority of the Government's overall policy objective, which stems from the country's development blueprint, the 'Zimbabwe Agenda for Sustainable Socio-Economic Transformation" (Zim Asset), October 2013December 2018. The Sustainable Livelihoods approach calls for a need to access capital, livelihood strategies, and decision-making powers through processes, such as policies, legislation, institutions, culture, and power relations. The study found that informal women traders doing business at flea markets are involved in unregistered savings and MCSs as pathways towards poverty eradication. These have been neglected over the past decades, in which Chirisa, (2008) confirms that "the closest they came 
to being registered is through subscriptions or having hawker's license that they pay to the city council". As expressed by the informal women traders, there are many challenges in their endeavours that require urgent attention by the blueprint specifically targeting informal women traders doing business at flea markets. The study noted that women doing business at flea markets could do well with adequate support from central Government, local institutions and international institutions. The interventions should be translated by not charging exorbitant prices at their places of business. Also, there is a need for local authorities to advertise the business on behalf of IWTs by creating external links or external markets regionally and abroad. The responses revealed that those who produce products locally lack markets to advertise their products.

The MCSs were initiated by IWTs without government or Non Governmental Organizations (NGO) support motivating them. The study found out that policies and legal frameworks are essential for quality implementation of the savings and MCSs of the women doing business at flea markets. Mulwa, (2008) reveal that, "unless registered, such schemes have no legal authority to sue or to be sued". Some practical examples of those supported are drawn from other countries where Government and Financial Institutions support such schemes by enacting comprehensive policies and legal frameworks which make them successful. The Government and Financial Institutions could have a significant role to play in assisting women doing business at flea markets by giving group members incentives for them to gain access and control over available resources. Mulwa, (2008) point out that "it is advisable that savings and credit schemes be facilitated or at least referred by a reputable organization which will oversee that the members' savings are safe". Several informal women traders expressed that they needed that kind of support (not remote control) in their initiatives from proficient agencies with expertise through effective monitoring and evaluation for them to address the problem of maladministration amongst themselves. The Sustainable Livelihoods Strategy which guides this study could support them by re-enforcing polices and legal frameworks as a form of control. The United Nations Development Fund for Women (UNIFEM) suggests that savings and MCSs are the key strategies to facilitate women traders to end poverty. The involvement of some financial institutions such as the World Bank, Global Fund for Women, Agri-Bank, Small and Medium Enterprises (SMEs), NGOs and many other financial institutions and a few small businesses is fundamental. The study found that some of these institutions are primarily concerned with those who are visible devoid of focusing on the small scale entrepreneurs. Mulwa, (2008) warns if of the view that "care should be taken to ensure loaning procedures and default penalties are strictly adhered to in order to safeguard against the problem of going out of hand". The findings of this study show that these institutions may provide soft loans to women doing business at flea markets to enhance their businesses and gain access and control of their livelihoods resources. Nyakudya (2012) argues that businesses of flea markets are now overcrowded although the aspect of savings and MCSs by women doing business at the flea market is important. The Government of Zimbabwe for example has the Constitution which is a legal document of the country which covers all aspects of the economy. The study acknowledges that Government has the responsibility to instate laws and regulations that will see every flea market and MCSs fitting in with the Zimbabwe Constitution of 2013 and the Government's overall policy objective, which stems from the country's development blueprint, the 'Zimbabwe Agenda for 
Sustainable Socio-Economic Transformation (Zim Asset, 2018). The Zimbabwe Poverty Report (2017) recognize the fact that eradicating poverty is a top priority of the Government's overall policy objective, which stems from the country's development blueprint, the 'Zimbabwe Agenda for Sustainable SocioEconomic Transformation (Zim Asset, 2018).

Thus Government policy documents already launched could establish opportunities through Commercial Banks for women doing business at flea markets for them to benefit towards poverty eradication. The study discovered that women involved in savings and MCSs at flea markets encounter numerous challenges in administering funds as well as paying back loans. The World Summit for Social Development held in Copenhagen in March 1995 called on Governments to review national, legal regulatory and institutional frameworks that restrict the access of poor women, especially. Kantz (2001) argues that depending on the agency, the approach could be used largely as an analytical framework (or tool) for programme planning and assessment or as a programme in itself. The study noted the need for Government to craft and implement sound policies and legal frameworks that pioneer the launching of incentives to informal women traders for them to enhance their capacities to do business as well as protect the interests of women doing business for poverty eradication. The World Report, (2018) enlighten that "implementing solutions has fallen short due to the lack of resources (both financial and human) and political will".

International Non Governmental Organizations like CARE, UNDP and DFID support household livelihoods security mainly at the community level. Some Multiple studies reveal that Government policies and legal frameworks are normally entrusted and mandated to local authorities to co-ordinate the programmes implemented at the district level. These agencies underline those sustainable livelihoods approaches enable policy environments, macro-economic reforms, and legislation as equally important for poverty reduction. The study found out that there is a great need for multi-stakeholder approaches to intervene through these various agencies since some of the agencies are co-ordinated by regional financial institutions. Other donor agencies involved in poverty eradication include, ILO, World Bank, UNDP and UNICEF. The SLA ought to be implemented to benefit women doing business at flea markets. This should promote vibrant micro-credit schemes that facilitate in the process of poverty eradication. The thrust of a multi-stakeholder approach, in the same way, initiate comprehensive micro-credit management training programmes that are in line with the aspirations of the World Summit for Social Development of March 1995. The SL Approach could also proffer a more holistic view on what resources, or combination of resources, are important for the poor, including not only physical and natural resources, but also their social and human capital (Kantz 2001). These efforts could embrace massive and robust pieces of training women in business management; capacity building workshops, education on gender issues and leadership workshops for capacity building and local empowerment required which are required to enhance the livelihoods of women involved in savings and MCSs at flea markets as pathways towards poverty eradication. The study found that if these interventions and sustainable strategies for informal women traders are implemented in line with the SIDA's SLA approach, this could effectively improve the livelihoods of poor women for poverty eradication. Kantz (2001) corroborates that the SLA has its strength in that "it facilitates an understanding of the underlying causes of poverty by focusing on the 
variety of factors, at different levels, that directly or indirectly determine or constrain poor people's access to resources/assets of different kinds, and thus their livelihoods". Kantz (2001) noted that "the SLA has its weaknesses in the way resources and other livelihood opportunities are distributed locally which is influenced by the existing informal structures of social dominance and power within the communities themselves; the issues which the UNDP and CARE seem not to address". Mulwa, (2008) is of the view that management committees should be formed by members to manage the scheme. The findings of this study demonstrate that these issues affect the livelihoods of informal women traders doing business at flea markets in the inner cycles of the HCBD in Zimbabwe. Chirisa, (2013) conclusively argue that "a good Governance approach is required to improve the livelihoods of women in the informal sector.

\section{Conclusion}

This study investigated the livelihoods strategies of the informal women traders doing business at flea markets as a strategy to eradicate poverty in Zimbabwe. The study was carried out at the flea markets in the HCBD of Harare Province. The study was informed by the Livelihood Framework proffered by SIDA, (2001) which is specifically developed for poverty eradication. The specific objectives of the study were designed; to identify various micro-credit schemes by IWTs doing business at flea markets, to explore the impact of MCSs as pathways towards poverty eradication and to determine comprehensive interventions and sustainable strategies that could be used by informal women traders under harsh socio-economic environment. Data was gathered through questionnaires, in-depth interviews, focus group discussions and direct observations. The study revealed that IWTs specialise in MCSs as their primary sources of livelihoods and flea markets have become attracting centre for women who want to do business in the HCBD. The MCSs enhance socio-economic development, set standards in poverty eradication and improves the lifestyles of IWTs. The responses demonstrated that many IWTs encounter numerous challenges resulting in finding it difficult to repay the loans. The study concluded that if financing institutions and Non Governmental Organizations could assist them through small bank loans; this would help them to gain access and control of their livelihoods resources in a meaningful manner. The study proposed a few livelihoods strategies that could be in the form of Macro Micro-Credit Schemes (MCSs) financed by big institutions such as the Global Fund for Women and the International Monitory Fund. The study conclusively provides that well-designed policy instruments help to free IWTs from poverty as well as increasing their participation in the economic and political processes of society in Zimbabwe.

\section{Abbreviations}

HCBD- Harare Central Business District

SIDA-Swedish International Development Cooperation Agency Division

SPSS-Statistical Computer Software Package

ZPR-Zimbabwe Poverty Report

Page 19/26 
MCSs-Micro-Credit Schemes

FBOs- Faith Based Organizations

UNSs- United Nations Systems

UNMDGs-United Nations Millennium Development Goals

SDGs- Sustainable Development Goals

WSSD-World Summit for Social Development

IWTs- Informal Women Traders

PDLA -Poverty Datum Line Analysis

Zimstats- Zimbabwe Statistical Agency

SLA-Sustainable Livelihood Approach

IDS- Institute for Development Studies

DFID- British Department for International Development

FGDs-Focus Group Discussion

USD-United States Dollar

PDL-Poverty Datum Line

ESAP-Economic Structural Adjustment

Zim Asset- Zimbabwe Agenda for Sustainable Socio-Economic Transformation

NGOs- Non Governmental Organizations

UNIFEM-Nations Development Fund for Women

SMEs -Small and Medium Enterprises

UNDP- United Nations Development Fund

DFID- Department for Foreign International Development

ILO-International Labour Organization

UNICEF-United Nations International Children's Fund 


\section{Declarations}

The work was conducted under the Department of Social Work of the University of Zimbabwe by Stella Chipo Takaza and Chipo Chitereka. We understand the methods used in this article and declare that the principal work contained in this article is original work and we are the responsible persons. This Journal gets the sole and exclusive right to publish the work for the full length of the copyright period and permissions for reproduced work. The article has not been previously published and is not under consideration elsewhere.

\section{Competing of interests in the field}

The research was conducted with the support of some stakeholders as part of an academic exercise. The collaborative efforts enabled the researchers to gain access to the informal women traders at sites.

\section{Availability of data and material}

Permission to collect data was sought from the local authorities who granted approval to access the study participants within their business premises. The informal women traders made decisions to participate in the study after adequate information was given that data after collection was for academic purposes. There was no coercion or any undue influence. The researchers assured the participants maximum confidentiality and anonymity through using numbers instead of names on the questionnaire tool guides.

\section{Authors' contributions}

The authors took part and guided the study and their inclusion to the publication has been gained and no one is 'ghost' writer.

\section{Funding}

The research project was self funded and no funding was received from anywhere else except from the initiatives of the researchers.

\section{Acknowledgements}

We would like to thank all the women informal traders who volunteered to participate in this study and shared their thoughts and feelings on the topic under investigation. We would like to thank all the informal women traders who freely shared their experiences in their businesses to fight poverty. Without all your generous support, this survey would not have been successful. We thank you all.

\section{References}

Adeel, Z. (2017). A Renewed Focus on Water Security within the 2030 Agenda for Sustainable Development Sustainability Science. Doe: 10.1007/s11625-017-0476-7. 
Chambers, R., and Conway, G. (1992), Sustainable Rural Livelihoods: Practical Concepts for the 21st Century. Discussion Paper 296, Institute for Development Studies.

Donnacadh, H., Duke, S., Francis, R. and Pratt, B. (1990). Income Generation Schemes for the urban poor; Development Guidelines No.4, Series Editor: Brian Pratt.

Kaseke E. (1995). Social Security and Redistribution: The Case of Zimbabwe's Social Security programmes. Westport, Green word Press.

Kasende, D., Asingwuire, N., Kyomundo, S. and Banungire, F. (2001), A Regional research project-Final Report for Uganda Country Studies Phase 11.Uganda.

Krantz, L. (2001). The Sustainable Livelihood Approach to Poverty Reduction: An Introduction thesustainable-livelihood-approach-to-poverty-reduction_2656 (3).pdf.

Mugabi N. (2010). A dissertation submitted to the Department of Sociology, Faculty of Social Sciences in partial fulfilment for the award of the Degree Master of Arts in Sociology of Makerere University.

Mupambireyi, F. C. P. (2015). PhD Thesis- An Analysis of the Challenges and Survival Strategies of the Informal Retail Clothing Sector in Zimbabwe: The case of Mupedzanhamo in Mbare in Harare.

Mupambireyi, P. F., Chaneta, I. \& Maravanyika, D. (2014), Operational challenges of informal trading: A case of Mbare Mupedzanhamo Flea Market in Harare, Zimbabwe. University of Zimbabwe Business Review, 2 (2), 77-87.

Mupambireyi, P. F.; Chaneta, I; Maravanyika, D., (2014) Characterization Of Traders In The Clothing Flea Market Business: A Case Of Mbare Mupedzanhamo And Avondale Flea Markets In Harare, Zimbabwe Research journal's Journal of Entrepreneurship Vol. 2 | No. 10 December | 2014.

Nueman, W.L. (1993). Social Research Methods: Qualitative and Quantitative Approaches. New York: Allyn and Bacon.

Mulwa, F. W, (2008) Participatory Monitoring and Evaluation of Community Projects: Common Based project monitoring, Qualitative Impact Assessment and People-Friendly Evaluation Methods. Pauline Publications Africa, Nairobi.

Pérez-Escamilla, R. (2017) 'Food Security and the 2015-2030 Sustainable Development Goals: From Human to Planetary Health'. Current Developments in Nutrition 1, e000513. doi:10.3945/cdn.117.000513.

Richman, D. (2009). Microcredit Schemes creates strong independent businesswomen: Independent Ethiopia. www.independent.co.uk-News-World-Africa Accessed 5/05/ 2018.

Scoones, I. (2009). 'Livelihoods and Rural Development' The Journal of Peasant Studies, Volume 36, (2009) - Issue 1. Pages 171-196/ Published Online: 07 May 2009. 
The Global Report on Food Crises Joint Analysis for better decisions. Available at: https://docs.wfp.org/api/documents/WFP0000114546/download/?

_ga=2.210372819.794964826.1591234253-154565221.1549606488.

The World Bank, (1990), the Informal Sector in Zimbabwe: The Role of Women. World Bank PHRWD, Washington.

United Nations Conference on Sustainable Development, the Future We Want The UN SDGs Full report of the Open Working Group of the General Assembly on Sustainable Development Goals (A/68/970), Available at http://undocs.org/A/68/970. Accessed 07/01/2016.

World Bank, (2020) Food Security Available at https://www.worldbank.org/en/topic/food-security.

World Food Programme, (WFP, (2017) Global Report on Food Crises. Available

at: http://www.who.org.http://www.wfp.org/aid-professionals. Accessed 21/02/2019.

www.grameen-info.org/what is micro-credit Accessed 16/ 01/2019.

www.ziviso.wordpress.com/2011/07/30/Avondale-flea-market, Avondale's Flea Market: Harare's Bargain Bonanza, Chief K. Marimba Biriwasha- Accessed 25/01/2019.

Zheke, H. (2010). Savings and Internal Lending Communities (SILC): The key to helping Zimbabwean Youth overcome Poverty-Harare.

Zimbabwe Constitution Amendment (No. 20 Act) (2013), Harare Zimbabwe

Zimbabwe Poverty Report (2017). Harare: Zimbabwe National Statistics Agency, Harare. Available at: http://www.zimstat.co.zw/wp-ontent/uploads/publications/Population/population/ICDS_2017.

Zimbabwe Poverty Report (2017). Harare: Zimbabwe National Statistics Agency.

\section{Figures}




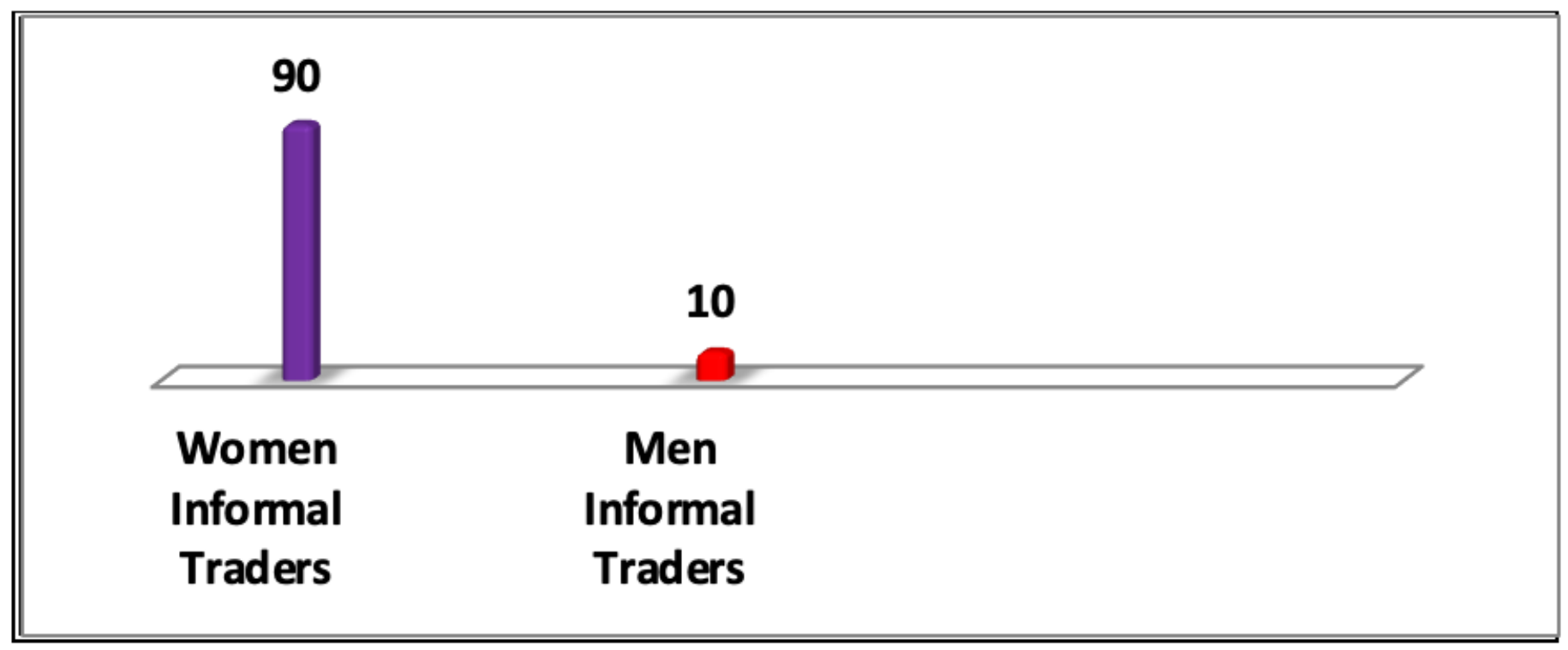

Figure 1

(labeled as "Figure 12" in the paper): Profile of the Respondents (No-100). Source: Analysis Source: Analysis from In-depth Interviews

\section{Image not available with this version}

Figure 2

Image not available with this version

Figure 3 


\section{Image not available with this version}

Figure 4

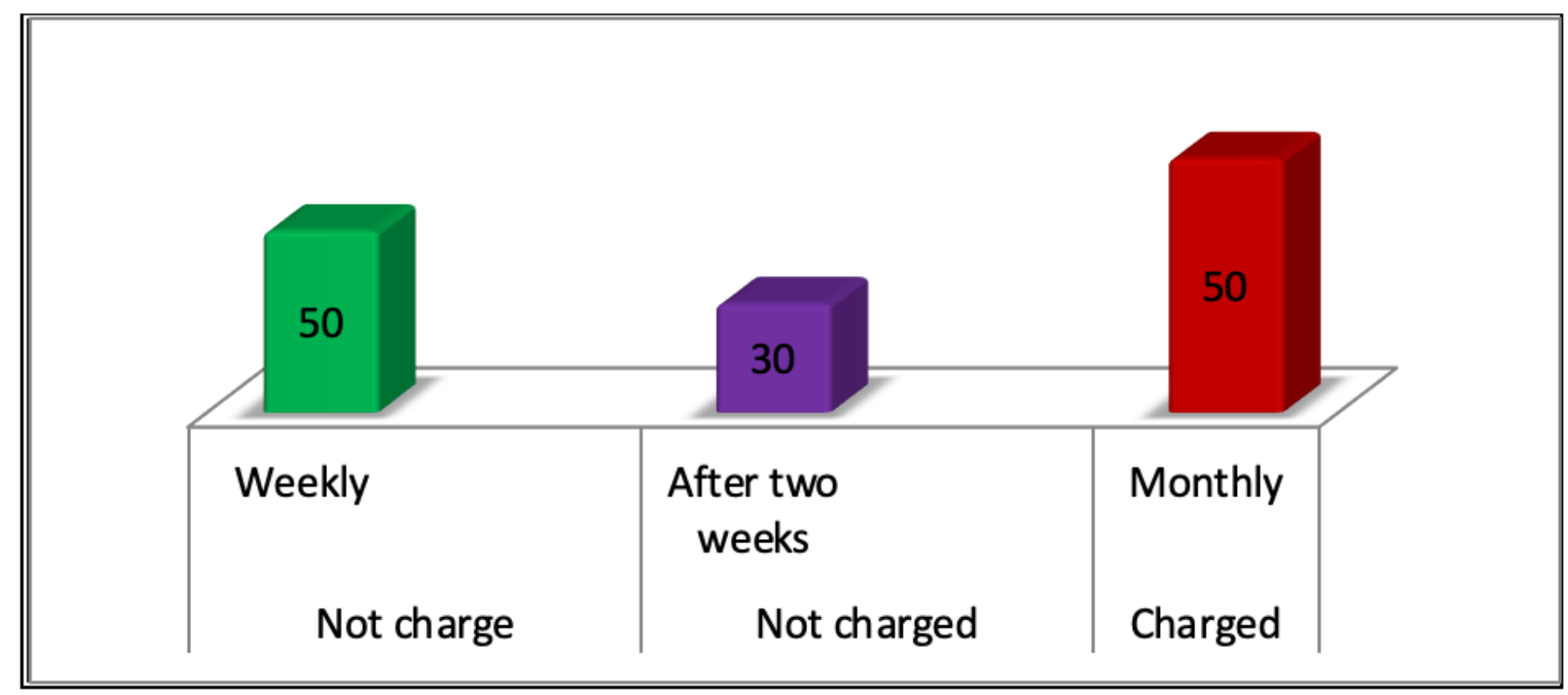

Figure 5

Terms of Payment by Numbers. Source: Calculation from in-depth interviews 


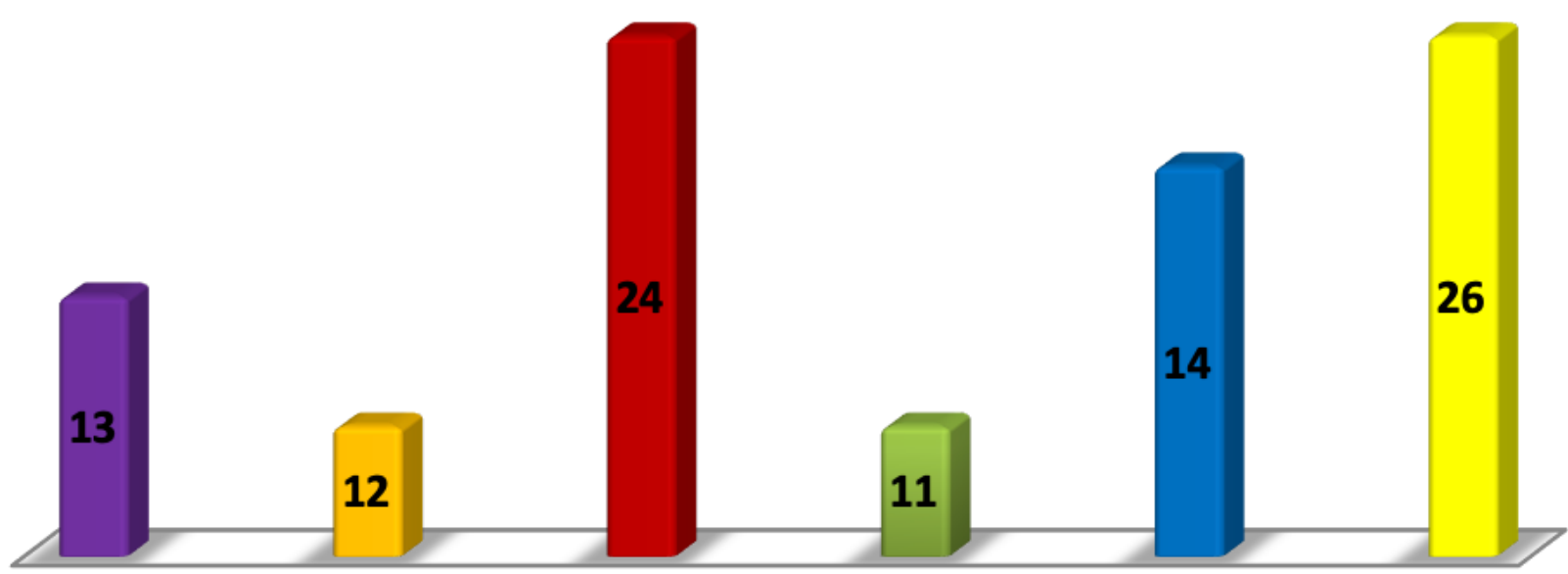

Health care Food stuffs EducationBuyiing and selliing Bus fare

Figure 6

How Women used the Money Borrowed (No-100). Source: Analysis from In-depth Interviews

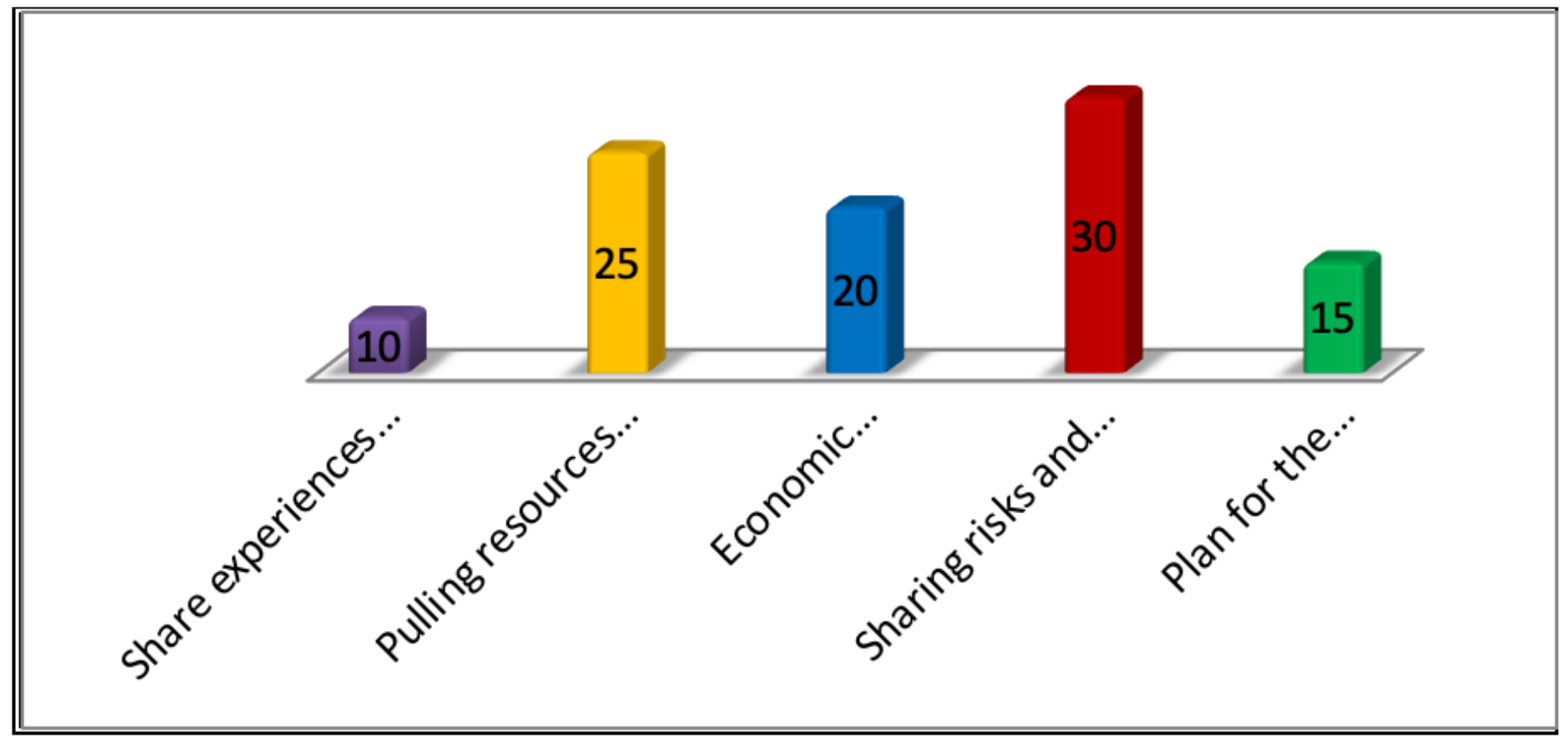

Figure 7

Reasons why Women Join MSs (No- 100). Source: Analysis from In-depth interviews 